\title{
MODEL PEMBELAJARAN KOOPERATIF TIPE INSIDE-OUTSIDE CIRCLE DALAM PEMBELAJARAN MATEMATIKA
}

\author{
Oleh: Nur Rahmah \& Rafika \\ Fakultas Tarbiyah \& IImu Keguruan IAIN Palopo \\ Email: nurrahmah_85@yahoo.co.id
}

\begin{abstract}
Abstrak
Penelitian ini bertujuan: mengetahui hasil belajar matematika siswa yang diajar dengan menggunakan model pembelajaran kooperatif tipe inside-outside circle (ioc) dan mengetahui hasil belajar matematika siswa yang tidak diajar dengan menggunakan model pembelajaran kooperatif tipe inside outside circle (ioc). Selain itu, mengetahui apakah terdapat perbedaan hasil belajar matematika pada siswa yang diberi perlakuan menggunakan model pembelajaran kooperatif tipe inside-outside circle (ioc) dan siswa yang tidak diberi perlakuan. Jenis penelitian ini adalah kuantitatif eksperimen tipe true experimental design dengan desain penelitian pretest-posttest control group design. Populasi dalam penelitian ini adalah siswa kelas VII SMP Negeri 7 Palopo yang terdiri atas 6 (enam) kelas dengan jumlah siswa 217. Pengambilan sampel, yakni dengan cara cluster random sampling. Berdasarkan analisis deskriptif diperoleh nilai rata-rata hasil belajar (post-test) untuk kelas kontrol 77,14, sedangkan nilai rata-rata hasil belajar (post-test) untuk kelas eksperimen 81,49. Hasil analisis statistik inferensial uji z dengan taraf signifikan $5 \%$, diperoleh nilai $z_{\text {hitung }}=2,218$ dan $z_{\text {tabel }}=1,645$ sehingga $z_{\text {hitung }}>$ $z_{\text {tabel }}(3,59>1,645)$ maka $H_{1}$ diterima. Artinya terdapat perbedaan hasil belajar matematika pada siswa yang diberi perlakuan dengan menggunakan model pembelajaran kooperatif tipe inside-outside circle (ioc) dan siswa yang tidak diberi perlakuan.
\end{abstract}

\section{Kata Kunci: Model Pembelajaran Kooperatif tipe Inside-Outside Circle (IOC), Hasil Belajar Matematika}

\section{A. Pendahuluan}

Pelajaran matematika selalu dipandang sebagai pelajaran yang sulit sehingga kurang diminati oleh banyak siswa. Pelajaran matematika yang diperoleh siswa selalu monoton dan disajikan kurang menarik oleh guru. Penggunaan model yang kurang tepat, dapat menimbulkan kebosanan, kurang dipahami, dan monoton sehingga siswa kurang termotivasi untuk belajar dan secara langsung hasil belajar ikut menurun.

Adapun hal yang perlu diperhatikan dalam upaya peningkatan kualitas pendidikan adalah penyelenggara proses pembelajaran. Fakta di lapangan menunujukkan bahwa hasil belajar siswa relatif rendah. Berdasarkan observasi awal yang dilakukan peneliti di kelas VII diperoleh kesimpulan bahwa hasil belajar siswa relatif rendah. Selain itu, hasil 
wawancara dengan guru matematika pada kelas tersebut juga mengatakan hal yang sama bahwa memang hasil belajar matematika untuk kelas tersebut rendah. Adapun kriteria ketuntasan minimum yang ditetapkan oleh sekolah adalah $\geq 75$. Kemudian, berdasarkan hasil observasi di kelas, ketika pembelajaran matematika berlangsung, metode yang digunakan oleh guru adalah metode konvensional, yaitu metode yang ditandai dengan ceramah yang diiringi dengan penjelasan serta pembagian tugas dan latihan, pembelajaran bersifat transfer ilmu, artinya guru mentransfer ilmu kepada siswanya, sedangkan siswa lebih banyak sebagai penerima. Sebagian besar siswa kelas VII masih pasif dalam belajar. Dengan kata lain, interaksi aktif antara siswa dan guru maupun siswa dengan siswa jarang terjadi, siswa cenderung belajar sendiri.

Salah satu penyebab rendahnya hasil belajar matematika adalah kurang aktifnya siswa dalam proses pembelajaran. Belum nampaknya keaktifan siswa dalam pembelajaran matematika itu terlihat dari masih banyaknya siswa yang kurang aktif dalam mengerjakan soal-soal latihan. Selain itu, siswa juga merasa bosan atau jenuh karena pembelajaran yang terjadi sangat monoton.

Mengacu dari kondisi yang telah diuraikan di atas maka masalah yang muncul adalah model pembelajaran apa yang dapat dikembangkan guru dalam upaya peningkatan hasil belajar matematika siswa? Peneliti tertarik untuk menerapkan suatu model pembelajaran yang diperkirakan mampu mendukung upaya peningkatan hasil belajar matematika siswa, yaitu model pembelajaran kooperatif. Model pembelajaran kooperatif selain membantu siswa memahami konsep-konsep yang sulit juga berguna untuk membantu siswa menumbuhkan keterampilan kerjasama dalam kelompoknya dan melatih siswa dalam berpikir kritis sehingga kemampuan siswa dalam memahami materi pelajaran yang disampaikan dapat meningkat.

Hal lain yang penting dalam pembelajaran kooperatif adalah dapat meningkatkan keaktifan dalam belajar siswa dan sikap yang positif, menambah motivasi belajar, dan percaya diri bagi siswa, menambah rasa senang berada di sekolah dan rasa sayang terhadap teman-teman sekelasnya. Pembelajaran kooperatif tidak sama dengan sekedar belajar dalam kelompok. Pelaksanaan prosedur model pembelajaran kooperatif dengan benar akan memungkinkan guru mengelola kelas lebih efektif. Model pembelajaran kooperatif akan dapat menumbuhkan pembelajaran efektif, yaitu pembelajaran yang 
bercirikan: (1) "memudahkan siswa belajar" sesuatu yang "bermanfaat" seperti, fakta, keterampilan, nilai, konsep, dan bagaimana hidup serasi dengan sesama; (2) pengetahuan, nilai, dan keterampilan diakui oleh mereka yang berkompeten menilai.

Salah satu model pembalajaran kooperatif, yaitu Inside-Outside Circle. Model pembelajaran kooperatif tipe Inside-Outside Circle ini siswa dituntut untuk bekerja secara berkelompok sehingga dapat memperkuat hubungan antara individu. Selain itu, model pembelajaran ini memerlukan keterampilan berkomunikasi dan proses kelompok yang baik. Dalam hal ini, model pembelajaran kooperatif tipe Inside-Outside Circle sangatlah tepat untuk pembelajaran.

Keunggulan dari model pembelajaran ini adalah adanya struktur yang jelas dan memungkinkan siswa untuk berbagi pengetahuan dengan pasangan yang jelas dan berbeda dengan singkat dan teratur. Selain itu, memungkinkan siswa untuk melatih kemampuan komunikasi siswa. Perbedaan dengan model pembelajaran kooperatif lain adalah Inside-Outside Circle mengharuskan dua siswa untuk berdiskusi dalam mengerjakan soal dan menyampaikan hasil diskusinya kepada siswa lain yang menjadi pasangan barunya dan mendengarkan hasil diskusi siswa lain sehingga terjadi pertukaran informasi antara siswa yang satu dan yang lainnya. Faktor inilah yang membuat siswa memahami materi. Beberapa keunggulan tersebut diharapkan penggunaan model pembelajaran ini dapat menciptakan pembelajaran matematika efektif sehingga secara langsung dapat meningkatkan hasil belajar siswa.

Berdasarkan latar belakang masalah di atas maka rumusan masalah dalam penelitian ini adalah sebagai berikut:

1. Bagaimana hasil belajar matematika siswa yang diajar dengan menggunakan model pembelajaran kooperatif tipe Inside-Outside Circle (IOC)?

2. Bagaimana hasil belajar matematika siswa yang tidak diajar dengan menggunakan model pembelajaran kooperatif tipe Inside-Outside Circle (IOC)?

3. Apakah terdapat perbedaan hasil belajar matematika pada siswa yang diberi perlakuan menggunakan model pembelajaran kooperatif tipe Inside-Outside Circle (IOC) dan siswa yang tidak diberi perlakuan? 


\section{B. Tinjauan Pustaka}

\section{Model Pembelajaran Kooperatif tipe Inside-Outside Circle (IOC)}

\section{a. Model Pembelajaran}

Mills berpendapat bahwa "model adalah bentuk reprensentasi akurat sebagai proses aktual yang memungkinkan seseorang atau sekelompok orang mencoba bertindak berdasarkan model itu". Model pembelajaran ialah pola yang digunakan sebagai pedoman dalam merencanakan pembelajaran di kelas maupun tutorial. Menurut Arends, model pembelajaran mengacu pada pendekatan yang akan digunakan, termasuk di dalamnya tujuan pembelajaran, tahap-tahap dalam kegiatan pembelajaran, lingkungan pembelajaran, dan pengelolaan kelas. Model pembelajaran dapat didefinisikan sebagai kerangka konseptual yang melukiskan prosedur sistematis dalam mengorganisasikan pengalaman belajar untuk mencapai tujuan belajar.

\section{b. Pembelajaran Kooperatif}

Cooperative berarti bekerja sama dan learning berarti belajar, jadi belajar melalui kegiatan bersama. Namun, tidak semua belajar bersama adalah cooperative learning, dalam hal ini belajar bersama melalui teknik-teknik tertentu. Pembelajaran kooperatif merupakan pembelajaran yang menekankan pada sikap atau perilaku bersama dalam bekerja atau membantu di antara sesama dalam struktur kerjasama yang teratur dalam kelompok yang terdiri atas dua atau lebih siswa untuk memecahkan masalah, sedangkan menurut Slavin cooperative learning adalah suatu model pembelajaran, yaitu siswa belajar dan bekerja dalam kelompok kecil secara kolaboratif yang anggotanya terdiri atas 4 sampai 6 orang, dengan struktur kelompoknya yang bersifat heterogen.

Keberhasilan dari model ini sangat tergantung pada kemampuan aktivitas anggota kelompok, baik secara individual maupun dalam bentuk kelompok. Cooperative Learning tidak sama dengan belajar kelompok, atau kelompok kerja, tapi memiliki struktur dorongan dan tugas yang bersifat cooperative, sehingga terjadi interaksi secara terbuka dan hubungan interdependensi yang efektif. Cooperative learning ini sangat menyentuh hakikat manusia sebagai makhluk sosial, yang selalu berinteraksi, saling membantu ke arah yang makin baik secara bersama "getting better together". Dalam proses belajar betul-betul diutamakan saling membantu di antar anggota kelompok. Jadi, pembelajaran 
kooperatif merupakan model pembelajaran yang menempatkan siswa sebagai bagian dari suatu sistem kerjasama untuk memaksimalkan belajar mereka dalam kelompok yang dapat mendorong siswa meningkatkan kemampuan pemecahan masalah.

\section{c. Model Pembelajaran Kooperatif Tipe Inside-Outside Circle (IOC)}

Pembelajaran dengan metode inside-outside circle diawali dengan pembentukan kelompok. Jika kelas terdiri atas 40 orang bagilah menjadi 2 kelompok besar. Tiap-tiap kelompok besar terdiri atas 2 kelompok lingkaran dalam jumlah anggota 10 dan kelompok lingkaran luar terdiri atas 10 orang.

Lingkaran dalam-lingkaran luar (Inside-Outside Circle) dikembangkan oleh Spencer Kagan. Teknik ini memungkinkan siswa untuk saling berbagi informasi pada waktu yang bersamaan. Salah satu keunggulan teknik ini adalah adanya struktur yang jelas dan memungkinkan siswa untuk saling berbagi informasi bersama dengan singkat dan teratur. Selain itu, memiliki banyak kesempatan untuk mengolah informasi dan meningkatakan keterampilan berkomunikasi.

Prosedur atau langkah-langkah model pembelajaran kooperatif tipe InsideOutside Circle:

1) Separuh kelas (atau seperempat jika jumlah siswa terlalu banyak) berdiri membentuk lingkaran kecil; mereka berdiri melingkar menghadap keluar. Separuh kelas lagi membentuk lingkaran besar; mereka berdiri menghadap ke dalam. Pola bentukan dari kedua lingkaran ini adalah: siswa-siswa dalam lingkaran kecil akan berada di dalam lingkaran siswa-siswa yang membentuk lingkaran besar, sehingga setiap siswa dalam lingkaran kecil nantinya akan berhadapan dengan siswa yang berada di lingkaran besar dan masing-masing akan menjadi pasangan.

2) Misalnya, anggap saja dalam satu ruang kelas terdapat 30 siswa. Siswa 1-15 membentuk lingkaran dalam, sedangkan siswa 16-30 membentuk lingkaran luar. Siswa 1 akan berhadapan dengan siswa 16; siswa 2 akan berhadapan dengan siswa 17; siswa 3 akan berhadapan dengan siwa 18; begitu seterusnya dalam bentuk lingkaran. 
3) Setiap pasangan siswa dari lingkaran kecil dan besar saling berbagi informasi. Siswa yang berada di lingkaran kecil (lingkaran dalam) dipersilakan memulai terlebih dahulu. Pertukaran informasi ini bisa dilakukan oleh semua pasangan dalam waktu yang bersamaan, namun tetap dengan nada bicara yang tenang (tidak telalu keras). Setelah itu, siswa yang berada di lingkaran besar (lingkaran luar) dipersilakan untuk berbagi informasi.

4) Kemudian, siswa yang berada di lingkaran kecil diam di tempat, sementara siswa yang berada di lingkaran besar bergeser satu atau dua langkah searah putaran jarum jam. Dengan cara ini, masing-masing siswa mendapatkan pasangan yang baru untuk berbagi informasi lagi.

5) Sekarang, giliran siswa yang berada di lingkaran besar yang membagikan informasi. Demikian seterusnya.

\section{d. Hasil Belajar Matematika}

Hasil belajar tidak dapat dipisahkan dari apa yang terjadi dalam kegiatan belajar baik dalam kelas, di sekolah maupun di luar sekolah. Evaluasi hasil belajar adalah proses untuk menentukan nilai belajar siswa melalui kegiatan penilaian dan atau pengukuran hasil belajar.

Dalam sistem pendidikan nasional rumusan tujuan pendidikan, baik tujuan kurikuler maupun tujuan intruksional, menggunakan klasifikasi hasil belajar dari Benyamin Bloom yang secara garis besar membagi tiga ranah, yakin ranah kognitif, ranah afektif, dan ranah psikomotorik. Ketiga objek tersebut menjadi objek penilaian hasil belajar. $\mathrm{Di}$ antara ketiga ranah itu, ranah kognitiflah yang paling banyak dinilai oleh para guru di sekolah karena berkaitan dengan kemampuan para peserta didik dalam menguasai isi bahan pengajaran.

Nana Sudjana dalam bukunya yang berjudul Penilaian Hasil Proses Belajar Mengajar mengemukakan bahwa hasil belajar sebagai kemampuan-kemampuan yang dimilki siswa setelah ia menerima pengalaman belajar. Hal-hal yang dipengaruhi hasil belajar adalah: 
1) Intelegensi dan penguasaan anak tentang materi yang akan dipelajari.

2) Adanya kesempatan yang diberikan oleh anak.

3) Motivasi.

4) Usaha yang dilakukan oleh anak.

Hamzah B. Uno dalam bukunya mengemukakan bahwa Reigeluth sebagaimana dikutip Keller menyebutkan bahwa hasil belajar adalah semua efek yang dapat dijadikan sebagai indikator tentang nilai dari penggunaan suatu metode di bewah kondisi yang berbeda. Menurut Reigeluth, hasil pengajaran dapat diklasifikasi menjadi tiga aspek, yakni (1) keefektifan pengajaran, (2) efisiensi pengajaran, (3) daya tarik pengajaran.

Hasil belajar merupakan indikator keberhasilan yang dicapai siswa dalam usaha belajarnya. Berdasarkan uraian tersebut, yang dimaksud hasil belajar matematika dalam penelitian ini adalah tingkat keberhasilan siswa menguasai bahan pelajaran matematika setelah mengikuti proses pembelajaran.

\section{Metode Penelitian}

Jenis penelitian yang digunakan dalam penelitian ini adalah penelitian eksperimen yang menggunakan dua kelas perlakukan, yaitu kelas kontrol yang diajar tanpa menggunakan model pembelajaran kooperatif tipe inside-outside circle (ioc) dan kelas eksperimen yang diajar menggunakan model pembelajaran kooperatif tipe insideoutside circle (ioc). Sebelum melaksanakan pembelajaran pada kedua kelas, terlebih dahulu diberikan soal pre-test untuk mengetahui kemampuan awal siswa.

Penelitian ini dilaksanakan di SMP Negeri 7 Palopo yang terletak di jalan Imam Bonjol No.8. Adapun populasi dalam penelitian ini yaitu seluruh siswa kelas VII SMP Negeri 7 Palopo yang terdiri atas 6 kelas dengan jumlah siswa 217. Kemudian dengan teknik cluster random sampling (pengambilan sampel secara acak) dipilih dua kelas, yakni kelas VIla sebagai kelas kontrol dan kelas VIIb sebagai kelas eksperimen.

Data dari penelitian ini bersumber dari pihak sekolah, guru dan siswa. Sebelum penelitian ini dilaksanakan terlebih dahulu penulis meminta izin kepada pihak sekolah, kemudian peneliti menghubungi guru matematika SMP Negeri 7 Palopo untuk menentukan jadwal kegiatan pelaksanaan. Sedangkan dari siswa penulis memperoleh data melalui 
hasil belajar dengan memberikan soal tes dalam bentuk essay dan lembar observasi untuk kedua kelas.

Teknik analisis data yang digunakan adalah statistik deskriptif dan inferensial. Sebelum melangkah ke analisis statistik deskriptif dan inferensial, instrumen yang akan diberikan kepada siswa terlebih dahulu diuji tingkat validitas dan reliabilitasnya. Adapun validitas yang digunakan dalam penelitian ini yaitu validitas isi ddan validitas item.

Analisis statistik deskriptif data dalam penelitian ini diperoleh dengan menggunakan program SPSS ver.20 for windows. Statistik inferensial digunakan untuk menguji hipotesis penelitian dengan menggunakan uji-z. Sebelum dilakukan pengujian hipotesis terlebih dahulu dilakukan uji homogenitas dan uji normalitas. Uji hipotesis dengan uji-z, dilakukan dengan menggunakan uji kesamaan dua rata-rata dan uji beda dua ratarata. Uji kesamaan dua rata-rata digunakan untuk mengetahui data pre-test (tes kemampuan awal siswa sebelum perlakuan) untuk kelas kontrol dan eksperimen mempunyai rata-rata yang sama atau tidak ada perbedaan yang signifikan. Sedangkan untuk uji beda dua rata-rata pada data post-test (tes hasil belajar sesudah perlakuan) kelas kontrol dan kelas eksperimen digunakan untuk mengetahui perbedaan rata-rata hasil belajar dari dua kelas tersebut.

\section{Hasil Penelitian dan Pembahasan}

Berdasarkan hasil validitas isi untuk soal pre test dan post test dari tiga validator diperoleh bahwa rata-rata skor total pre test dari beberapa aspek penilaian $(\bar{X})$ adalah0,815 dan rata-rata skor total post test dari berbagai aspek penilaiaian $(\overline{\mathrm{X}})$ adalah 0,7225. Dengan demikian, dapat disimpulkan bahwa soal pre test telah memenuhi kategori"0,80-1,00" yang dnilai sangat valid dan soal post test telah memenuhi kategori "0,60-0,79" yang dinilai valid dan dapat digunakan pada tahap selanjutnya. Adapun untuk hasil validitas item, yaitu soal dikatakan valid jika $r_{\text {hitung }} \geq r_{\text {tabel }}$ dan tidak valid jika $r_{\text {hitung }}<$

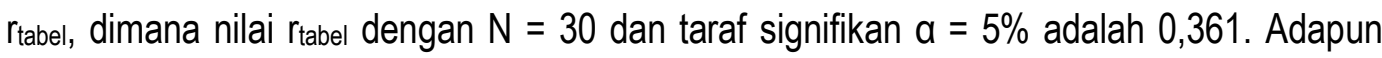
rincian hasil uji instrument dapat dilihat dalam tabel berikut: 
Tabel Hasil Validitas item tes hasil belajar

\begin{tabular}{|c|c|c|c|c|}
\hline \multirow{2}{*}{ No. } & \multicolumn{3}{|c|}{ Validitas } \\
\cline { 2 - 5 } & $\mathrm{R}_{\mathrm{xy}}$ & Ket & $\mathrm{R}_{\mathrm{xy}}$ & Ket \\
\cline { 2 - 5 } & 0,55194 & Valid & 0,54663 & Valid \\
\hline 1 & 0,50463 & Valid & 0,70127 & Valid \\
\hline 2 & 0,5917 & Valid & 0,66962 & Valid \\
\hline 3 & 0,66465 & Valid & 0,60144 & Valid \\
\hline 5 & 0,57241 & Valid & 0,40788 & Valid \\
\hline
\end{tabular}

Setelah mendapatkan hasil validitas, selanjutnya soal pre-test dan post-test tersebut reliabilitasnya dihitung. Berdasarkan hasil perhitungan reliabilitas, diperoleh nilai reliabilitas untuk soal pre-test yaitu 0,431 yang reliabel dengan kategori cukup. Sedangkan untuk soal post-test yaitu 0,515 yang reliabel dengan kategori sangat cukup. Sehingga soal pre-test dan post-test tersebut dapat diberikan kepada siswa.

Berdasarkan hasil analisis deskriptif dengan menggunakan program SPSS ver. 20 for windows, maka diperoleh nilai rata-rata pre test untuk kelas kontrol 69,4 dan untuk kelas eksperimen 66,77 . Nilai rata-rata tersebut jika dikelompokkan dalam empat kategori sesuai yang ditentukan oleh sekolah, maka nilai rata-rata pre-test untuk kelas kontrol dan eksperimen termasuk dalam kategori kurang. Sedangkan nilai rata-rata post-test untuk kelas kontrol 77,14 dan untuk kelas eksperimen 81,49. Nilai rata-rata tersebut jika dikelompokkan dalam empat kategori, maka nilai rata-rata post-test untuk kelas kontrol termasuk dalam kategori cukup, sedangkan untuk nilai rata-rata post-test kelas eksperimen termasuk dalam kategori baik.

Selanjutnya berdasarkan hasil pengolahan data statistik inferensial untuk uji homogenitas diperoleh bahwa populasi siswa kelas VII SMP Negeri 1 Palopo homogen. Adapun untuk uji normalitas, berdasarkan pengujian yang telah dilakukan diperoleh data yang berdistribusi normal. Berdasarkan perhitungan untuk uji kesamaan rata-rata data pretest kelas kontrol dan kelas eksperimen, diperoleh $z_{\text {hitung }}=1,28$ dan $z_{\text {tabel }}=1,96$. Karena $z_{\text {hitung }}<z_{\text {tabel }}$ yaitu $1,28<1,96$, maka $H_{0}$ diterima dan $H_{1}$ ditolak. Artinya bahwa tidak terdapat perbedaan rata - rata antara kelompok kontrol dan kelompok 
eksperimen. Sedangkan untuk uji beda dua rata-rata data post-test kelas kontrol dan kelas

eksperimen, diperoleh $z_{\text {hitung }}=2,218$ dan $z_{\text {tabel }}=1,645$. Karena $z_{\text {hitung }}>z_{\text {tabel }}$ yaitu 2,218 $>1,645$, berdasarkan kriteria pengujian yang telah ditentukan, maka $H_{1}$ diterima dan $H_{0}$ ditolak. Dapat disimpulkan bahwa terdapat perbedaan hasil belajar matematika siswa pada kelas yang diajar dengan menggunakan model pembelajaran kooperatif tipe Inside-Outside Circle (IOC) dan yang tidak diberi perlakuan.

Terjadinya perbedaan nilai hasil belajar matematika peserta didik tersebut, disebabkan karena adanya perbedaan perlakuan pada dua kelas yaitu kelas eksperimen yang menggunakan model pembelajaran kooperatif tipe inside outside circle (ioc) dan kelas kontrol yang tidak diberikan perlakuan apapun pada pembelajaran matematika. Dimana nilai hasil belajar matematika peserta didik pada hasil post-test setelah adanya perlakuan atau diberikan model pembelajaran kooperatif tipe inside outside circle (ioc) lebih meningkat dari pada hasil post-test pada kelas kontrol yang tidak diberikan perlakuan.

Keberhasilan dari model ini sangat tergantung pada kemampuan aktivitas anggota kelompok, baik secara individual maupun dalam bentuk kelompok. Cooperative learning tidak sama dengan belajar kelompok, atau kelompok kerja tapi memiliki struktur dorongan dan tugas yang bersifat cooperative, sehingga terjadi interaksi secara terbuka dan hubungan yang efektif. Cooperative learning ini sangat menyentuh hakikat manusia sebagai makhluk sosial, yang selalu berinteraksi, saling membantu ke arah yang makin baik secara bersama "getting better together". Dalam proses belajar betul-betul diutamakan saling membantu di antar anggota kelompok.

Pada pertemuan pertama, pembelajaran dengan menggunakan model pembelajaran kooperatif tipe inside outside circle (ioc) dalam pelaksanaannya terdapat berbagai hambatan. Salah satu hambatan yang paling mendasar yaitu peserta didik belum terbiasa dengan model pembelajaran kooperatif tipe inside outside circle yang diberikan oleh guru. Hambatan lain yang ditimbulkan yaitu waktu sering banyak terbuang apabila peserta didik tidak dapat menjawab pertanyaan yang diberikan oleh guru.

Hambatan-hambatan yang terjadi pada pertemuan pertama perlahan-lahan mulai berkurang pada pertemuan selanjutnya. Sehingga peserta didik sudah mulai terbiasa dan 
tertarik dengan menggunakan model pembelajaran kooperatif tipe inside outside circle (ioc).

Berdasarkan hasil observasi lembar pengamatan aktivitas siswa untuk kelas eksperimen dengan menggunakan daftar cek, dapat dilihat pada persentase rata-rata jumlah siswa yang memiliki hasil observasi dengan kategori sangat baik, baik, cukup, kurang dan sangat kurang pada tabel pengamatan aktivitas siswa mulai dari pertemuan pertama sampai keempat sebagai berikut:

Tabel: Hasil Observasi Aktivitas Siswa Kelas Eksperimen

\begin{tabular}{|l|c|c|c|c|}
\hline \multirow{2}{*}{ Pertemuan } & \multicolumn{4}{|c|}{ Persentase Rata-Rata } \\
\cline { 2 - 5 } & Perhatian & Partisipasi & Kemampuan & Kerjasama \\
\hline Pertama & $60 \%$ & $60 \%$ & $64 \%$ & $59 \%$ \\
\hline Kedua & $60 \%$ & $65 \%$ & $67 \%$ & $61 \%$ \\
\hline Ketiga & $74 \%$ & $71 \%$ & $73 \%$ & $74 \%$ \\
\hline Keempat & $84 \%$ & $86 \%$ & $84 \%$ & $83 \%$ \\
\hline
\end{tabular}

Pada kelas kontrol, pembelajaran yang tidak menggunakan model pembelajaran kooperatif tipe inside-outside circle dengan menggunakan daftar cek, dapat dilihat pada persentase rata-rata jumlah siswa yang memiliki hasil observasi kategori baik sekali, baik, cukup, dan kurang, dapat dilihat pada tabel pengamatan aktivitas siswa mulai dari pertemuan pertama sampai keempat sebagai berikut:

Tabel: Hasil Observasi Aktivitas Siswa Kelas Kontrol

\begin{tabular}{|l|c|c|c|c|}
\hline \multirow{2}{*}{ Pertemuan } & \multicolumn{4}{|c|}{ Persentase Rata-rata } \\
\cline { 2 - 5 } & Perhatian & Partisipasi & Kemampuan & Kerjasama \\
\hline Pertama & $56 \%$ & $60 \%$ & $58 \%$ & $55 \%$ \\
\hline Kedua & $60 \%$ & $62 \%$ & $63 \%$ & $62 \%$ \\
\hline Ketiga & $67 \%$ & $64 \%$ & $72 \%$ & $69 \%$ \\
\hline Keempat & $71 \%$ & $69 \%$ & $72 \%$ & $67 \%$ \\
\hline
\end{tabular}

Dari hasil observasi kelas kontrol, dimulai dari pertemuan pertama hingga akhir pembelajaran menunjukkan adanya peningkatan aktivitas namun tidak sebaik dengan hasil observasi di kelas eksperimen. 


\section{E. Kesimpulan}

Adapun kesimpulan yang diperoleh dari penelitian ini adalah sebagai berikut.

1. Hasil belajar matematika siswa kelas VII SMP Negeri 7 Palopo yang diajar dengan menggunakan model pembelajaran kooperatif tipe inside outside circle (ioc) berada pada kategori baik dengan perolehan rata-rata sebesar 81,49. Berdasarkan perolehan persentase hasil belajar matematika siswa, dapat dilihat bahwa dari 35 siswa pada kelas eksperimen, 5 siswa (14,3\%) yang termasuk kategori baik sekali, 17 siswa (48,6\%) yang termasuk kategori baik, 7 siswa $(20 \%)$ yang termasuk kategori cukup dan 6 siswa $(17,1 \%)$ yang termasuk dalam kategori kurang.

2. Hasil belajar matematika siswa kelas VII SMP Negeri 7 Palopo yang tidak diajar dengan menggunakan model pembelajaran kooperatif tipe inside outside circle (ioc) berada pada kategori cukup dengan perolehan rata-rata sebesar 77,14. Perolehan persentase hasil belajar pada kelas kontrol, yaitu dari 35 siswa diperoleh 2 siswa (5,7\%) yang termasuk kategori baik sekali, 14 siswa (40\%) yang termasuk kategori baik, 9 siswa $(25,8 \%)$ yang termasuk kategori cukup dan 10 siswa $(28,5 \%)$ yang termasuk dalam kategori kurang.

3. Berdasarkan hasil penelitian yang dianalisis dengan statistik inferensial ini dapat dilihat dari hasil uji hipotesis (uji-z) diperoleh $Z_{\text {hitung }}>Z_{\text {table }}(2,218>1,645)$ bahwa terdapat perbedaan hasil belajar matematika pada siswa yang diberi perlakuan dengan menggunakan model pembelajaran kooperatif tipe inside-outside circle (ioc) dan siswa yang tidak diberi perlakuan. Dengan demikian, dapat disimpulkan hasil belajar kelas yang diberi perlakuan kelas VIIb (kelas eksperimen) berupa penggunaan model pembelajaran kooperatif tipe inside-outside circle (ioc) lebih baik dari hasil belajar matematika siswa kelas $\mathrm{VII}_{a}$ (kelas kontrol), yaitu siswa yang tidak diberi perlakuan. 


\section{DAFTAR PUSTAKA}

Alma, Buchari. Guru Profesional Menguasai Metode dan Terampil Mengajar. Edisi Revisi. Bandung: Alfabeta, 2012.

Arikunto, Suharsimi. Prosedur Penelitian Suatu Tindakan Praktek. Ed.V. Cet. XIII. Jakarta: Rineka Cipta, 2006.

Azwar, Zaifuddina. Reliabilitas dan Validitas.Edisi 4. Jogjakarta: Pustaka Pelajar, 2013.

Budiarti, Cory Eka. Penerapan Model Pembelajaran Kooperatif Tipe Inside-Outside Circle Untuk Meningkatkan Kemampuan Komunikasi Matematik Siswa Kelas VIII MTsN Tangerang II Pamulang. Skripsi. Jakarta; UIN Syarif Hidayatullah, 2010.

Danim, Sudarwan. Pengantar Kependidikan Landasan Teori dan 234 Metafora Pendidikan. Bandung: Alfabeta, 2011.

Departemen Agama RI. Al- Qur’an dan Terjemahannya. Jakarta: Pelita II, 1978.

Departemen Pendidikan dan Kebudayaan RI. Kamus Besar Bahasa Indonesia. Cet, X. Jakarta: Balai Pustaka, 1999.

Dimyati dan Mudjiono. Belajar dan Pembelajaran. Jakarta: Rineka Cipta, 1999.

Dwirahayu, Gelar dan Munasprianto Ramli. Pendekatan Baru dalam Pembelajaran Sains dan Matematika Dasar. Jakarta: IAIN Indonesia Social Equity Project, 2007.

Huda, Miftahul. Cooperative Learning Metode, Teknik, Struktur dan Model Terapan. Cet.I. Yogyakarta: Pustaka Belajar, 2011.

Husain Usman dan Purnomo Setiady Akbar, Pengantar Statistik, Jakarta : Bumi Akasara, 2000

John M. Echols dan Hasan Shadily, Kamus Inggris Indonesia, Jakarta : Gramedia Pustaka Utama, 2000.

Margono, S. Penelitian Pendidikan, Cet. II. Jakarta: Rineka Cipta, 2003.

Nasution. Metode Research (Penelitian IImiah). Cet. IV. Jakarta: Bumi Aksara, 2001.

Nurhayani, Penerapan Model Pembelajaran Kooperatif Tipe Inside-Outside Circle Untuk Meningkatkan Hasil Belajar IPS Siswa Kelas VIIb SMP Muhammadiyah 17 Ciputat Tahun Ajaran 2014/2015. Skripsi. Jakarta; UIN Syarif Hidayatullah, 2014.

Riduwan, Belajar Mudah Penelitian. Bandung: Alfabeta, 2010. 
Saliman dan Sudarsono. Kamus Pendidikan Pengajaran dan Umum. Cet. I. Jakarta: Rineka Cipta, 1994.

Solihatin, Etin dan Raharjo. Cooperative Learning Analisis Model Pembelajaran IPS. Jakarta: Bumi Aksara, 2007.

Subana dan Sudrajat. Dasar - Dasar Penelitian IImiah. Cet. II. Bandung: Pustaka Setia, 2005.

Sudjana. Nana. Penilaian Hasil Belajar Mengajar. Bandung: Remaja Rosdakarya, 2006.

Sugiyono, Statistika untuk Penelitian. Cet. XII. Bandung: Alfabeta, 2007.

Sukardi. Metodologi Penelitian Pendidikan. Cet.1. Jakarta:Bumi Aksara, 2003.

Sukmadinata, Nana Syaodih. Metode Penelitian Pendidikan. Cet. V. Bandung: Remaja Rosdakarya, 2009

Suprijono, Agus. Kumpulan Metode Pembelajaran Cooperative Learning Teori dan Aplikasi Paikem. Surabaya, 2012.

Syah, Muhibbin. Psikologi Pendidikan dengan Pendekatan Baru. Bandung: PT Remaja Rosdakarya, 2010.

Tim Penyusun Pusat Bahasa. Kamus Bahasa Indonesia. Jakarta: Pusat Bahasa, 2008.

Wardi, dkk. UURI Nomor 20 Tahun 2003 tentang Sistem Pendidikan Nasional, Peraturan Pemerintah RI Nomor 19 Tahun 2005 Tentang Standar Nasional Pendidikan, peraturan Pemerintah RI Nomor 47 Tahun 2008 Tentang Wajib Belajar. Jogjakarta: 